Article

\title{
High Temperature Anti-Friction Behaviors of a-Si:H Films and Counterface Material Selection
}

\author{
Qunfeng Zeng ${ }^{1,2, *}$ and Liguo Qin ${ }^{1}$ \\ 1 Key Laboratory of Education Ministry for Modern Design and Rotor-Bearing System, \\ Xi'an Jiaotong University, Xi'an 710049, China \\ 2 College of Materials Science and Engineering, Yangtze Normal University, Chongqing 408100, China \\ * Correspondence: qzeng@xjtu.edu.cn
}

Received: 21 June 2019; Accepted: 13 July 2019; Published: 18 July 2019

\begin{abstract}
In the present paper, the influence of self-mated friction materials on the tribological properties of hydrogenated amorphous silicon films (a-Si:H films) is studied systemically at high temperature. The results are obtained by comparing the tribological properties of a-Si:H films under different friction pair materials and temperatures. The a-Si:H films exhibit super-low friction of 0.07 at a temperature of $600{ }^{\circ} \mathrm{C}$, and ceramic materials are appropriate for anti-friction behaviors of a-Si: $\mathrm{H}$ films at high temperature. The results of tribotests and observations of the fundamental friction mechanism show that super-low friction of a-Si:H films and ceramic materials of the friction system are involved in high temperature oxidation; this also applies to the tribochemical reactions of a-Si:H films, steel and iron silicate in open air at elevated temperature in the friction process.
\end{abstract}

Keywords: hydrogenated amorphous silicon films; high temperature oxidation; super-low friction

\section{Introduction}

With the rapid development of military, aerospace and industrial robots, equipment have been run under harsh operating conditions such as high temperature. It is well known that the tribological problem is one of the scientific challenges of engineering applications in friction systems under high temperature conditions [1]. Moreover, high temperature evokes tribological properties of machinery parts that are complicated due to the tribological chemistry reaction at high temperature and friction heating [2-4]. Diamond-like carbon (DLC) films have been the subject of intensive studies in recent years and exhibit a number of attractive tribological properties such as super-low friction and DLC films being considered excellent candidate materials for tribological applications below $300{ }^{\circ} \mathrm{C}[5-7]$. In open air, DLC films are confined to the environmental temperature above $300{ }^{\circ} \mathrm{C}$ where oxidation occurs. In a previous work, a superlubricity system relating to DLC films at high temperature was proposed. Moreover, the lubricious composite oxides are generated from the interlayer of hydrogenated amorphous silicon films (a-Si:H films) at the interface due to tribochemistry reactions in the friction process [8]. Therefore, it was concluded that a-Si:H films are beneficial to produce lubricious oxides and achieve high temperature super-low friction. It would be expected to resolve high friction problems of high temperature tribology in industrial applications [9,10]. The a-Si:H films were deposited on a steel substrate and the tribological properties of a-Si:H films were investigated under high temperature. The a-Si:H films exhibit super-low friction under high temperature [11].

The tribological properties of materials depends on many factors such as temperature, applied load, sliding velocity, and properties of matting materials. Due to the complexity of friction phenomena in composite oxides, the friction mechanisms are not fully understood. Therefore, it is necessary to build an anti-friction system and probe high temperature anti-friction behaviors of a-Si:H films and clarify high temperature anti-friction and oxidation mechanisms of the a-Si:H film-related friction systems 
to extend the wide tribological applications of a-Si:H films under high temperature. The aim of the present work is to investigate the influence of friction-matted materials for high temperature antifriction behavior of a-Si:H films and select appropriate friction-pair materials for a-Si:H films in open air from 200 to $600{ }^{\circ} \mathrm{C}$. High temperature super-low friction and the super-low friction mechanism of a-Si:H films are expected to achieve and clarify the potential engineering applications at high temperature.

\section{Experimental Details}

\subsection{Preparation of a-Si:H Films}

The a-Si:H films were deposited on high speed tool steel (HSS) flats in a plasma-enhanced chemical vapor deposition (PECVD) system, with a mix gas of $\mathrm{Ar}$ and $\mathrm{SiH}_{4}$. Ar gas is introduced into a chamber to clean the ambient air for $5 \mathrm{~min}$. Then, $\mathrm{SiH}_{4}$ gas is used to deposit hydrogenated amorphous silicon films for $2 \mathrm{~h}$. After deposition of films, Ar gas is introduced into the chamber again to clear the reaction gas of $\mathrm{SiH}_{4}$. The deposition pressure is about $80 \mathrm{~Pa}$. The thickness of the a-Si:H films is $1 \mu \mathrm{m}$. The deposition details of hydrogenated amorphous silicon films are given in our previous paper [11].

\subsection{Characterization of a-Si:H Films}

Raman spectroscopy (HR800, Horbia Jobin Yvon, Villeneuve d'Ascq, France) with 633 nm and a resolution of $1 \mathrm{~cm}^{-1}$ was employed to estimate the microstructure of a-Si:H films. All Raman spectra were measured at room temperature to avoid heating the sample. As expected, the measurement of Fourier Transform Infrared Spectrometry (FTIR, Nicolet iS50, Thermo Fisher Scientific, Madison, WI, USA) was also performed to analyze the microstructure of a-Si:H films.

\subsection{High Temperature Tribotests of a-Si:H Films}

Tribotests of a-Si:H films were carried out by a high-temperature tribometer (Universal Tribometer, Rtec Instruments, San Jose, CA, USA) to investigate the friction and wear behaviors of a-Si:H films and influence of the friction-pair materials of a steel ball, $\mathrm{ZrO}_{2}$ ball, $\mathrm{Si}_{3} \mathrm{Ni}_{4}$ ball and DLC films-coated steel ball on the tribological properties of a-Si:H films at the temperatures of 200,400 and $600{ }^{\circ} \mathrm{C}$ in ambient air. The a-Si:H films-coated disc was slid against the ball at a speed of $0.05 \mathrm{~m} / \mathrm{s}$ and applied load of $5 \mathrm{~N}$. The friction pairs were cleaned by the ultrasound device in acetone and then blown by dry air before tests and measurements. The microstructure of the worn surface of ball and flat was investigated by Raman spectroscopy within the wear scar zone. Surface morphology of the worn surface of the ball and flat was observed by optical microscopy after tribotests.

\section{Results and Discussion}

\subsection{Raman Spectra and FTIR of a-Si:H Films}

Figure 1 shows Raman spectrum of a-Si:H films on a flat. The films exhibit a strong Raman peak at $480 \mathrm{~cm}^{-1}$, showing amorphous silicon, and a weak peak at $220 \mathrm{~cm}^{-1}$, showing hydrogenated amorphous silicon. The band at $2000 \mathrm{~cm}^{-1}$ is assigned to the stretching vibration of Si-H bond and the peak at $630 \mathrm{~cm}^{-1}$ is assigned to the bending vibration of $\mathrm{Si}-\mathrm{H}$ bond in FTIR. It also indicates there is hydrogen in amorphous silicon films. In the FTIR spectrum of a-Si:H films, the strong bands at 630, 2018 and $2178 \mathrm{~cm}^{-1}$ are the typical and characteristic peaks of a-Si:H films [12]. The band at $630 \mathrm{~cm}^{-1}$ belongs to the $\mathrm{Si}-\mathrm{H}$ bond. It is also found that the absorption peaks of $\mathrm{SiH}$ and $\mathrm{SiH}_{2}$ are observed occurring to peaks at 2018 and $2178 \mathrm{~cm}^{-1}$. According to FTIR measurements, the obtained a-Si:H films contain lots of hydrogen. There are asymmetric $\mathrm{Si}-\mathrm{O}-\mathrm{Si}$ stretching vibrations at $1040 \mathrm{~cm}^{-1}$ and a $\mathrm{Si-O}-\mathrm{Si}$ bending mode at $890 \mathrm{~cm}^{-1}$ in FTIR spectrum. 

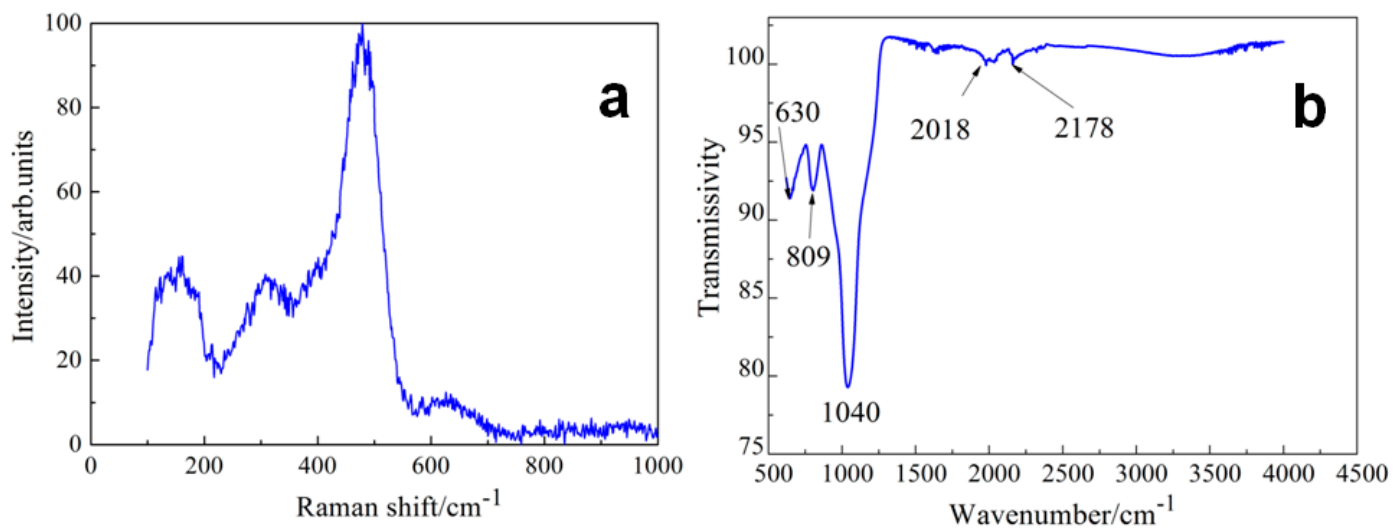

Figure 1. (a) Raman and (b) FTIR spectrum of a-Si:H films.

\subsection{Tribological Properties of Steel Ball/a-Si:H Films under Different Temperatures}

Figure 2 shows $\mathrm{CoF}$ of steel ball/a-Si:H films under different testing temperatures. At $200{ }^{\circ} \mathrm{C}$, initial $\mathrm{CoF}$ is 0.4 and fluctuates subsequently to 0.47 . At $400{ }^{\circ} \mathrm{C}$, initial $\mathrm{CoF}$ is 0.26 and average $\mathrm{CoF}$ is 0.36. However, there is a big difference in the CoF curve between 400 and $600{ }^{\circ} \mathrm{C}$. At $600{ }^{\circ} \mathrm{C}$, initial $\mathrm{CoF}$ is 0.35 and then drops down to around 0.1 and average $\mathrm{CoF}$ is 0.09 . It is found that a-Si:H films exhibit excellent high temperature anti-friction behavior at $600{ }^{\circ} \mathrm{C}$.

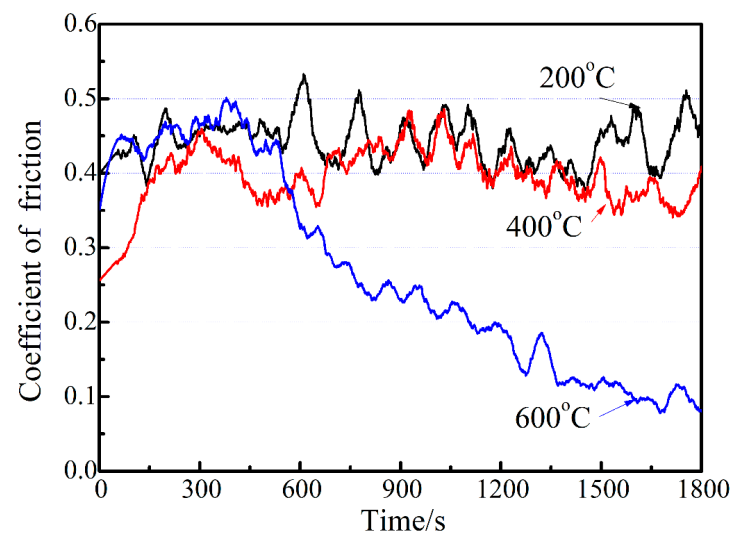

Figure 2. CoF of steel ball/a-Si:H films under different temperatures.

The topography of the worn surfaces was investigated by a non-contact profilometer (CX40M, Sunny Instruments Co., Ltd., Ningbo, China). Figure 3 shows surface topography of the worn surface of ball and flat at $600^{\circ} \mathrm{C}$. The wear scar width on flat is about $824.0 \mu \mathrm{m}$ and the wear track width of ball is $1436.2 \mu \mathrm{m}$ at $600{ }^{\circ} \mathrm{C}$. There are lots of black materials on wear scar on disc and wear debris with circle scar on ball. It seems that there are chemical reactions due to environmental high temperature and friction heating and oxidation products on wear scar during sliding.

The a-Si:H films exhibit super-low friction at $600^{\circ} \mathrm{C}$. The structure and component of the worn surface of the friction pair are indispensable to be measured at $600{ }^{\circ} \mathrm{C}$. Figure 4 shows SEM (S-3000N, Hitachi, Tokyo, Japan) image and Raman spectrum of steel ball/a-Si:H films friction pair at $600{ }^{\circ} \mathrm{C}$. Figure 4a shows SEM image of the worn surface of disc. There are some small and circle particles in the wear scar on disc. Figure 4b shows Energy Dispersive X-ray Spectroscopy (EDS, S-3000N, Hitachi) of the worn surface of disc. There are $\mathrm{Si}, \mathrm{O}$ and Fe elements in the wear scar, which indicates that there are tribological chemistry reactions and maybe $\mathrm{SiO}_{2}$ and iron oxides after tribotests. Figure $4 \mathrm{c}$ shows a typical peak of $\mathrm{Fe}_{3} \mathrm{O}_{4}$. The band at $665.2 \mathrm{~cm}^{-1}$ is the typical peak of $\mathrm{Fe}_{3} \mathrm{O}_{4}$ about $\mathrm{A}_{1 \mathrm{~g}}$ model. The peak at $537.1 \mathrm{~cm}^{-1}$ is the typical peak of $\mathrm{Fe}_{3} \mathrm{O}_{4}$ for the $\mathrm{T}_{2 \mathrm{~g}}(2)$ model and the peak at $291.0 \mathrm{~cm}^{-1}$ is the typical peak of $\mathrm{Fe}_{3} \mathrm{O}_{4}$ about the $\mathrm{E}_{\mathrm{g}}$ model. The peak of $1320.2 \mathrm{~cm}^{-1}$ is the characteristic peak of 
$\alpha-\mathrm{Fe}_{2} \mathrm{O}_{3}$. Figure $4 \mathrm{~d}$ shows Raman spectrum of a-Si:H films. The peak at $660.3 \mathrm{~cm}^{-1}$ is the main peak of $\mathrm{Fe}_{3} \mathrm{O}_{4}$. The band of $660.3 \mathrm{~cm}^{-1}$ is the typical peaks of $\alpha-\mathrm{Fe}_{2} \mathrm{O}_{3}$, and there are bands at $223.7 \mathrm{~cm}^{-1}$ of $\alpha-\mathrm{Fe}_{2} \mathrm{O}_{3}, 290.2 \mathrm{~cm}^{-1}$ of $\alpha-\mathrm{Fe}_{2} \mathrm{O}_{3}, 409.7 \mathrm{~cm}^{-1}$ of $\alpha-\mathrm{Fe}_{2} \mathrm{O}_{3}$ and $611.4 \mathrm{~cm}^{-1}$ of $\alpha-\mathrm{Fe}_{2} \mathrm{O}_{3}$ [13]. These measurements show these oxides include $\alpha-\mathrm{Fe}_{2} \mathrm{O}_{3}$ and $\mathrm{Fe}_{3} \mathrm{O}_{4}$ except for a-Si:H films on the worn surface of ball and flat. The peak at $940 \mathrm{~cm}^{-1}$ is actually the typical peak of Si-O-Si bond stretching. According to Raman measurements and tribotest results, there are iron oxides of $\alpha-\mathrm{Fe}_{2} \mathrm{O}_{3}$ and $\mathrm{Fe}_{3} \mathrm{O}_{4}$ on ball and the composite oxides of $\alpha-\mathrm{Fe}_{2} \mathrm{O}_{3}$ and $\mathrm{SiO}_{2}$ with few $\mathrm{Fe}_{3} \mathrm{O}_{4}$ on flat. Therefore, the friction pair is iron oxides of $\alpha-\mathrm{Fe}_{2} \mathrm{O}_{3}$ and $\mathrm{Fe}_{3} \mathrm{O}_{4}$ and self-generated composite oxides of $\alpha-\mathrm{Fe}_{2} \mathrm{O}_{3}$ and $\mathrm{SiO}_{2}$ on the flat through high temperature oxidation reaction, which results in high temperature super-low friction at the temperature of $600{ }^{\circ} \mathrm{C}$.

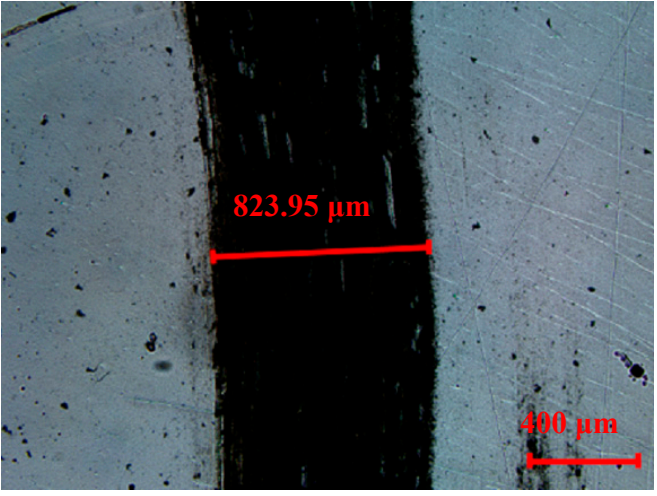

(a)

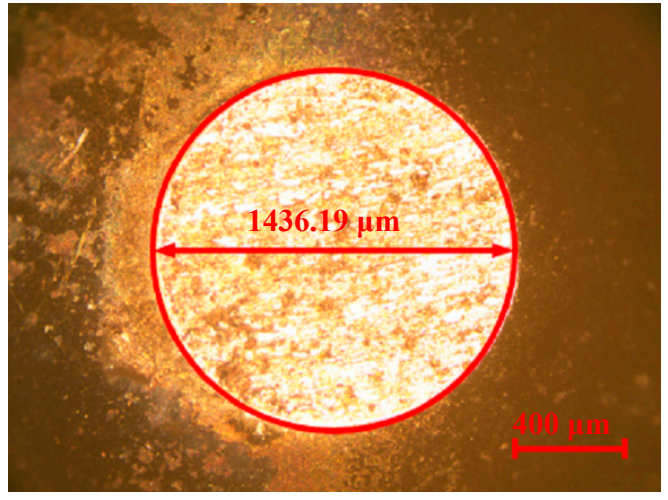

(b)

Figure 3. Images of wear scar of steel ball/a-Si:H films at $600^{\circ} \mathrm{C}$ : (a) disc; (b) ball.
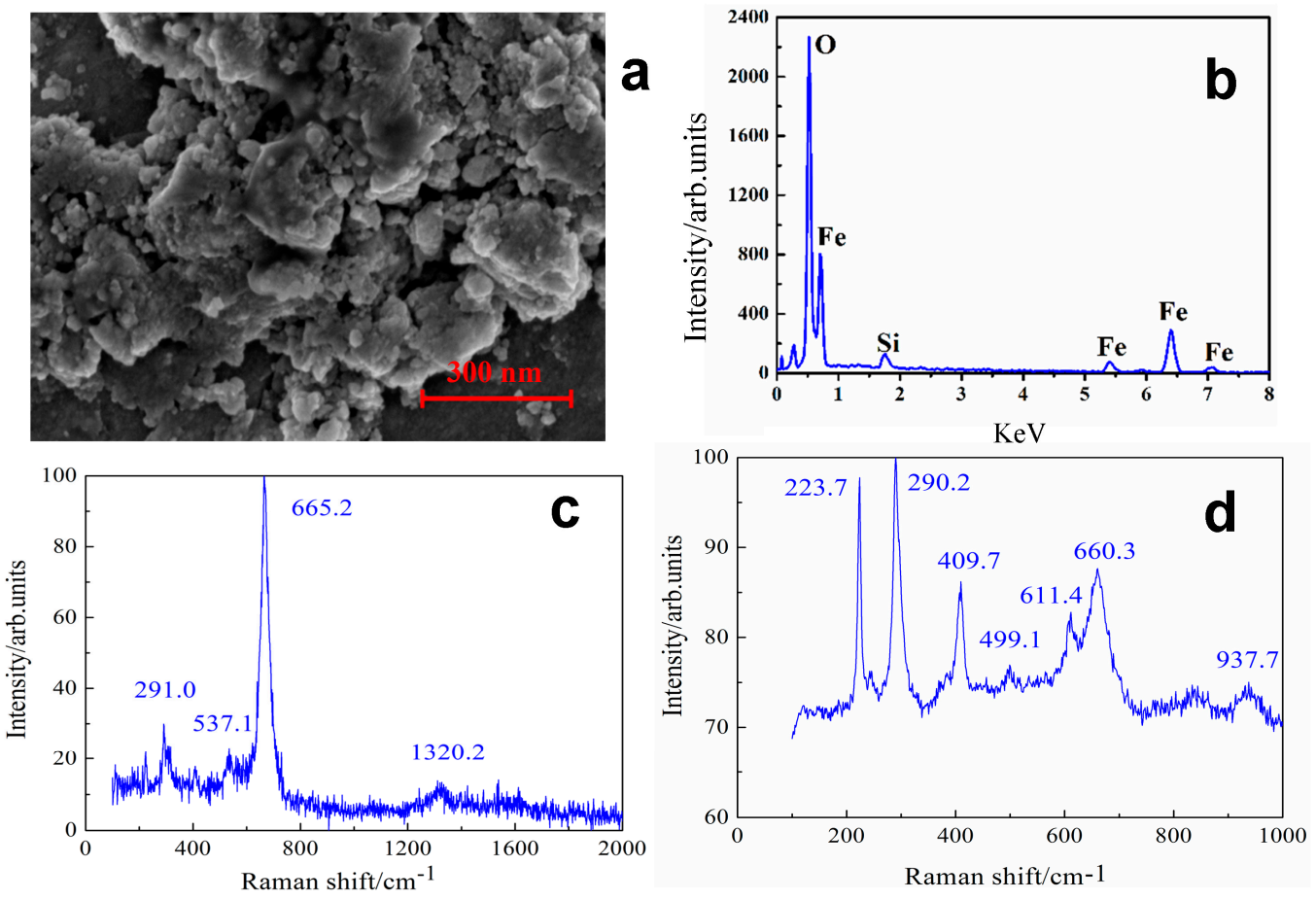

Figure 4. SEM images and EDS of wear scar of disc and Raman spectrum of steel ball/a-Si:H films: (a) SEM images and (b) EDS spectroscopy of wear scar disc at $600^{\circ} \mathrm{C}$. (c) Raman spectrum of wear scar on ball. (d) Raman spectrum of wear scar on disc. 


\subsection{Tribological Properties of DLC Films on Steel Ball/a-Si:H Films under Different Temperatures}

Figure 5 shows CoF of DLC films on steel ball/a-Si:H films under different tribotest temperatures. At $200{ }^{\circ} \mathrm{C}$, initial $\mathrm{CoF}$ is 0.1 and fluctuates to 0.38 until the end of tribotest. At $400{ }^{\circ} \mathrm{C}$, initial $\mathrm{CoF}$ is 0.49 and then fluctuates to the maximum value of 0.56 and finally CoF decreases to below 0.1 after $1000 \mathrm{~s}$. The average $\mathrm{CoF}$ is 0.08 . At $600{ }^{\circ} \mathrm{C}$, initial $\mathrm{CoF}$ is 0.36 and then goes down slowly to below 0.1 and average $\mathrm{CoF}$ is about 0.07. The antifriction behaviors of DLC films/a-Si:H films are different these of steel ball/a-Si:H films, especially in high temperature. At $400{ }^{\circ} \mathrm{C}, \mathrm{CoF}$ of steel ball/a-Si:H films is low at the initial stage and fluctuates on a stable stage, however, CoF of DLC films/a-Si:H films is high at the initial stage and then decreases slightly to low $\mathrm{CoF}$ after the maximum value. At $600{ }^{\circ} \mathrm{C}, \mathrm{CoF}$ of steel ball/a-Si:H films reaches the maximum value and decreases slightly to low $\mathrm{CoF}$ at a stable stage, however, CoF of DLC films/a-Si:H films decreases to low CoF with the increase of sliding time.

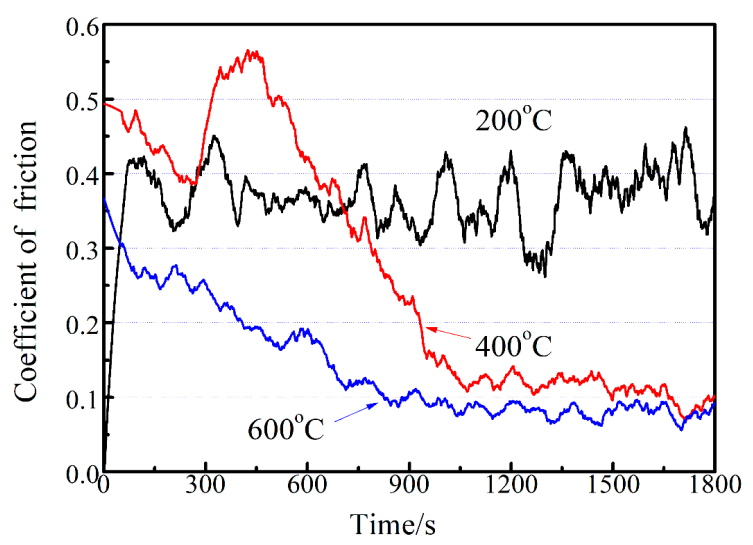

Figure 5. CoF of DLC films on steel ball/a-Si:H films under different temperatures.

Figure 6 shows the surface topography of the worn surface of ball and flat at $600{ }^{\circ} \mathrm{C}$. The wear track width of flat is about $795.4 \mu \mathrm{m}$ and the wear track width of ball is $1456.1 \mu \mathrm{m}$ at $600{ }^{\circ} \mathrm{C}$. There are also lots of black materials on the wear scar on the flat, however, there is not only wear debris in the wear scar but also few deep plough grooves in the circle wear scar on ball.

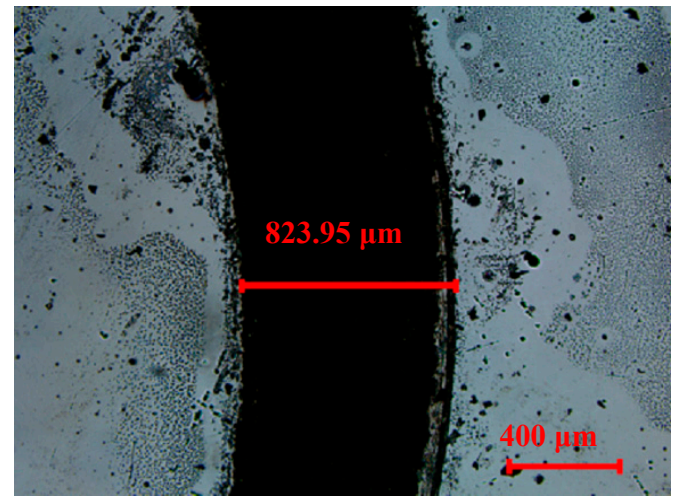

(a)

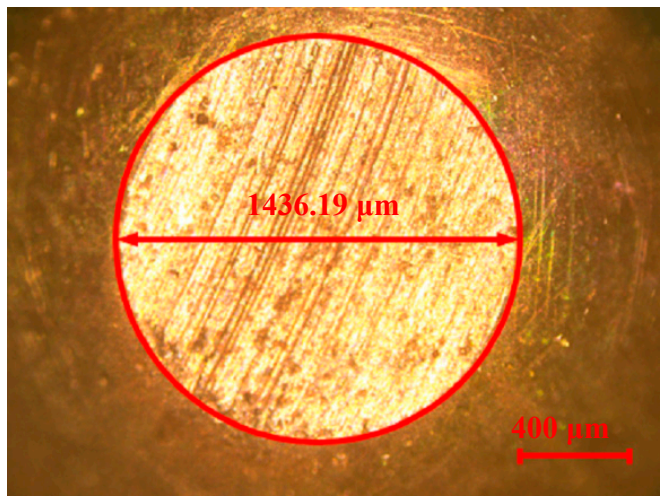

(b)

Figure 6. Images of wear scar of DLC films on steel ball/a-Si:H films at $600{ }^{\circ} \mathrm{C}$ : (a) disc; (b) ball.

Figure 7 shows Raman spectra of DLC films/a-Si:H films at $600^{\circ} \mathrm{C}$. For ball, the most representative bands of hematite ( $\alpha$ phase) are around 228.6 and $295.2 \mathrm{~cm}^{-1}$. The $507.5 \mathrm{~cm}^{-1}$ band is due to SiC lattice vibrations that were recorded in the sample. The region of the Raman spectrum in which spectral features associated with carbon inclusions could be expected. The spectrum contains one strongly resolved band $\left(1324.8 \mathrm{~cm}^{-1}\right)$ band that is probably due to carbon present (graphitic phase) at this point in the sample in the $s p^{3}$ configuration. The Si-O-Si modes of silicate chains appear at $668.6 \mathrm{~cm}^{-1}$. It 
can be seen that transverse (TO) at $1049.6 \mathrm{~cm}^{-1}$ Si modes appear weak in the spectra. Figure $7 \mathrm{~b}$ shows Raman spectrum of the disc. There are bands of $227.9 \mathrm{~cm}^{-1}$ of $\alpha-\mathrm{Fe}_{2} \mathrm{O}_{3}$ with $\mathrm{A}_{1 \mathrm{~g}}$ model, $287.4 \mathrm{~cm}^{-1}$ of $\alpha-\mathrm{Fe}_{2} \mathrm{O}_{3}$ with $\mathrm{E}_{\mathrm{g}}(3)$ model. The temperature produced by the friction heating will result in the oxidation of the steel substrate. Hence Raman spectrum shows significantly intense modes at 287.4 and $405.2 \mathrm{~cm}^{-1}$ which correspond to $\alpha-\mathrm{Fe}_{2} \mathrm{O}_{3}$, but the Raman mode at $1308.2 \mathrm{~cm}^{-1}$ is not affected significantly. According to Raman measurements and tribotest results, there are mainly $\alpha-\mathrm{Fe}_{2} \mathrm{O}_{3}$ with few $\mathrm{SiC}$ and carbon on ball and the oxides of $\alpha-\mathrm{Fe}_{2} \mathrm{O}_{3}$ and $\mathrm{SiO}_{2}$ on flat. Therefore, the friction pair exhibits better anti-friction behavior than those for DLC films/a-Si:H films at $600{ }^{\circ} \mathrm{C}$ because there are carbon-related materials on the contact surface.
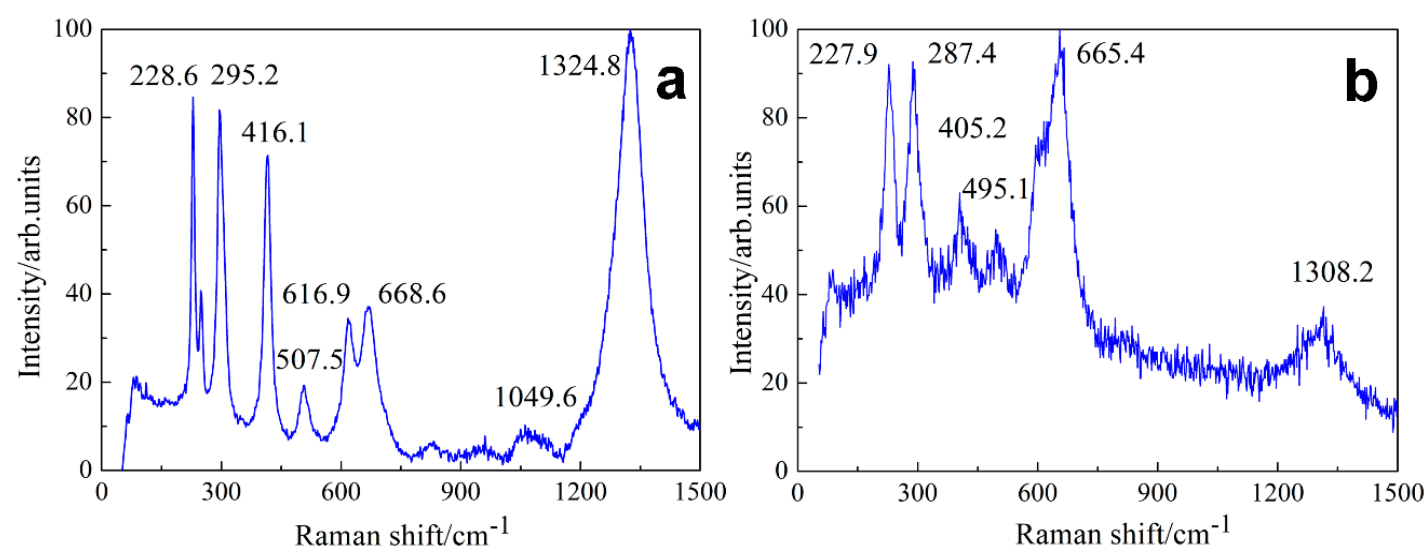

Figure 7. Raman spectrum of wear scar of DLC films/silicon films under different temperatures: (a) ball; (b) disc.

\subsection{Tribological Properties of $\mathrm{ZrO}_{2}$ Ball/a-Si:H Films under Different Temperatures}

Figure 8 shows $\mathrm{CoF}$ of $\mathrm{ZrO}_{2}$ ball/a-Si:H films under different tribotesting temperatures. At $200{ }^{\circ} \mathrm{C}$, initial $\mathrm{CoF}$ is 0.35 and decreases to around 0.2 at the stable stage. At $400{ }^{\circ} \mathrm{C}$, initial $\mathrm{CoF}$ is 0.3 and decreases to around 0.2. The average $\mathrm{CoF}$ is 0.2 . At $600{ }^{\circ} \mathrm{C}$, initial $\mathrm{CoF}$ is 0.22 and then goes down slowly to 0.1 and average $\mathrm{CoF}$ is about 0.07 . It is found that $\mathrm{CoF}$ of $\mathrm{ZrO}_{2}$ ball/a-Si:H films is relatively low at the initial stage and $\mathrm{CoF}$ is also low at the stage comparing other friction pairs, especially at high temperature.

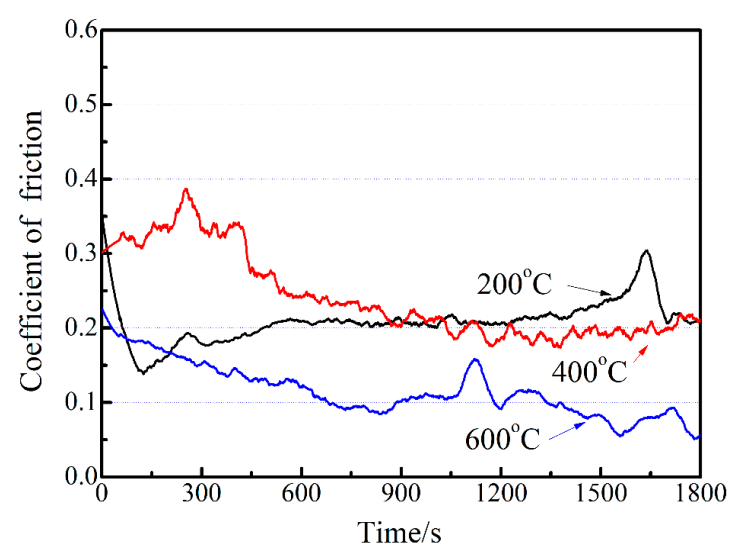

Figure 8. $\mathrm{CoF}$ of $\mathrm{ZrO}_{2}$ ball/a-Si:H films under different temperatures.

\subsection{Tribological Properties of $\mathrm{Si}_{3} \mathrm{~N}_{4}$ Ball/a-Si:H Films under Different Temperatures}

Figure 9 shows $\mathrm{CoF}$ of $\mathrm{Si}_{3} \mathrm{~N}_{4}$ ball/a-Si:H films under different testing temperatures. At $200{ }^{\circ} \mathrm{C}$, initial $\mathrm{CoF}$ is 0.3 and decreases to around 0.33 at the stable stage. At $400{ }^{\circ} \mathrm{C}$, initial $\mathrm{CoF}$ is 0.3 and decreases to around 0.2. The average $\mathrm{CoF}$ is 0.21 . At $600^{\circ} \mathrm{C}$, initial $\mathrm{CoF}$ is 0.24 and then decreases 
slowly to below 0.1 and average $\mathrm{CoF}$ is about 0.07. It is found that $\mathrm{CoF}$ of $\mathrm{Si}_{3} \mathrm{~N}_{4}$ ball/a-Si:H films is also relatively low at the initial stage and $\mathrm{CoF}$ is also low at the stage comparing other friction pairs, especially in high temperature. It means that $\mathrm{Si}_{3} \mathrm{~N}_{4}$ is suitable for using as frictional matted material for a-Si:H films and the friction pair exhibits lower than that of $\mathrm{ZrO}_{2}$ ball, which is important to get super-low friction and high wear-resistance.

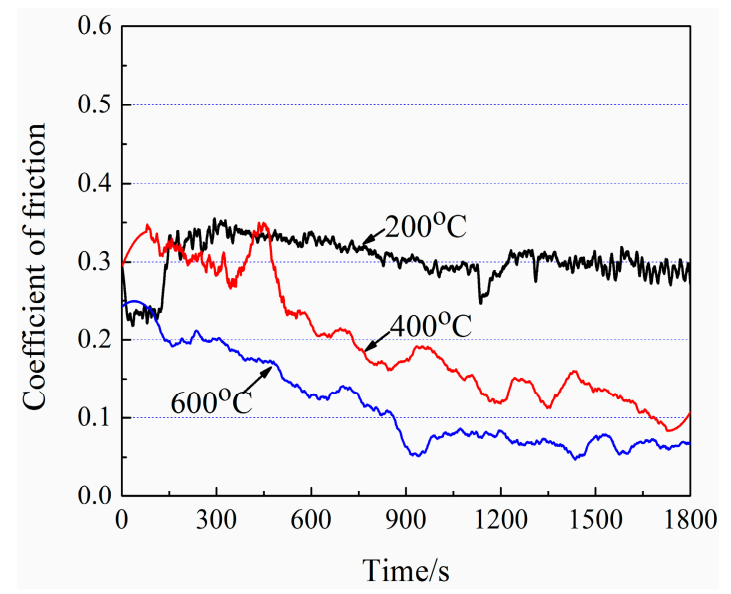

Figure 9. $\mathrm{CoF}$ of $\mathrm{Si}_{3} \mathrm{Ni}_{4}$ ball/a-Si:H films under different temperatures.

Figure 10 shows surface topography of the worn surface on ball and flat under different temperatures. The wear scar width of flat is about $775.7 \mu \mathrm{m}$ and the wear scar width of ball is $889.5 \mu \mathrm{m}$ at $600{ }^{\circ} \mathrm{C}$. It is found that the width of $\mathrm{Si}_{3} \mathrm{~N}_{4}$ ball/a-Si:H films is low. There are some black materials on the wear scar on flat and there are wide plough grooves in wear scar of ball; it seems that the ball surface looks smooth and few wear debris, which means that the iron oxides adhered hardly to $\mathrm{Si}_{3} \mathrm{~N}_{4}$ ball and reduce the friction and adhesion.
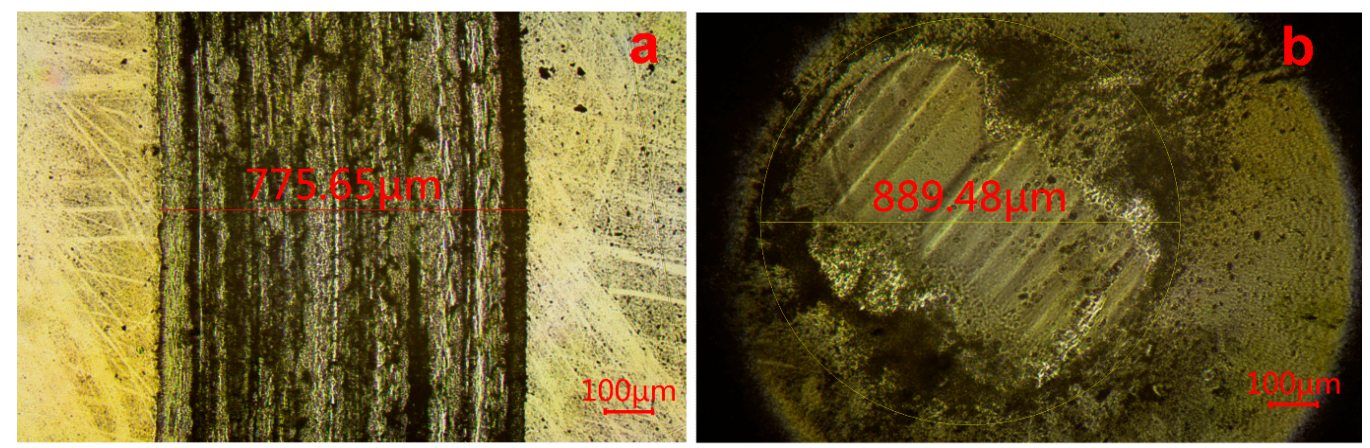

Figure 10. Images of wear scar of $\mathrm{Si}_{3} \mathrm{~N}_{4}$ ball/a-Si:H films at $600{ }^{\circ} \mathrm{C}$ : (a) a-Si:H; (b) ball.

Figure 11 shows Raman spectrum of $\mathrm{Si}_{3} \mathrm{~N}_{4}$ ball/a-Si:H films at $600{ }^{\circ} \mathrm{C}$. Note the low frequency mode at $182.0 \mathrm{~cm}^{-1}$ because this is an external vibration model of $\mathrm{Si}_{3} \mathrm{~N}_{4}$. The shifts of the bands at 182, 203, 861.8 and $926.7 \mathrm{~cm}^{-1}$ have been observed. These bands are the characteristic bands of $\mathrm{Si}_{3} \mathrm{~N}_{4}$. The bands in the low frequency range at 615.8 and $658.8 \mathrm{~cm}^{-1}$ are associated with the overlapping of the symmetrical stretching vibrations and the bending vibrations of $\mathrm{Si}-\mathrm{O}-\mathrm{Si}$ bonds of silicate chains. Figure $11 \mathrm{~b}$ shows the Raman spectrum of a flat. There are bands of $225.9 \mathrm{~cm}^{-1}$ of $\alpha-\mathrm{Fe}_{2} \mathrm{O}_{3}$ with $\mathrm{A}_{1 \mathrm{~g}}$ model, $291.9 \mathrm{~cm}^{-1}$ of $\alpha-\mathrm{Fe}_{2} \mathrm{O}_{3}$ with $\mathrm{E}_{\mathrm{g}}(3)$ model. Therefore, the Raman spectrum shows a significantly intense mode at $409.9 \mathrm{~cm}^{-1}$ which corresponds to $\alpha-\mathrm{Fe}_{2} \mathrm{O}_{3}$. According to Raman measurements and tribotest results, there is mainly $\mathrm{Si}_{3} \mathrm{~N}_{4}$ or few $\alpha-\mathrm{Fe}_{2} \mathrm{O}_{3}$ on ball and the composite oxide of $\alpha-\mathrm{Fe}_{2} \mathrm{O}_{3}$ and $\mathrm{SiO}_{2}$ on the flat. The friction pair exhibits better anti-friction behaviors than those for $\mathrm{Si}_{3} \mathrm{~N}_{4}$ ball/a-Si:H films at $600{ }^{\circ} \mathrm{C}$. 

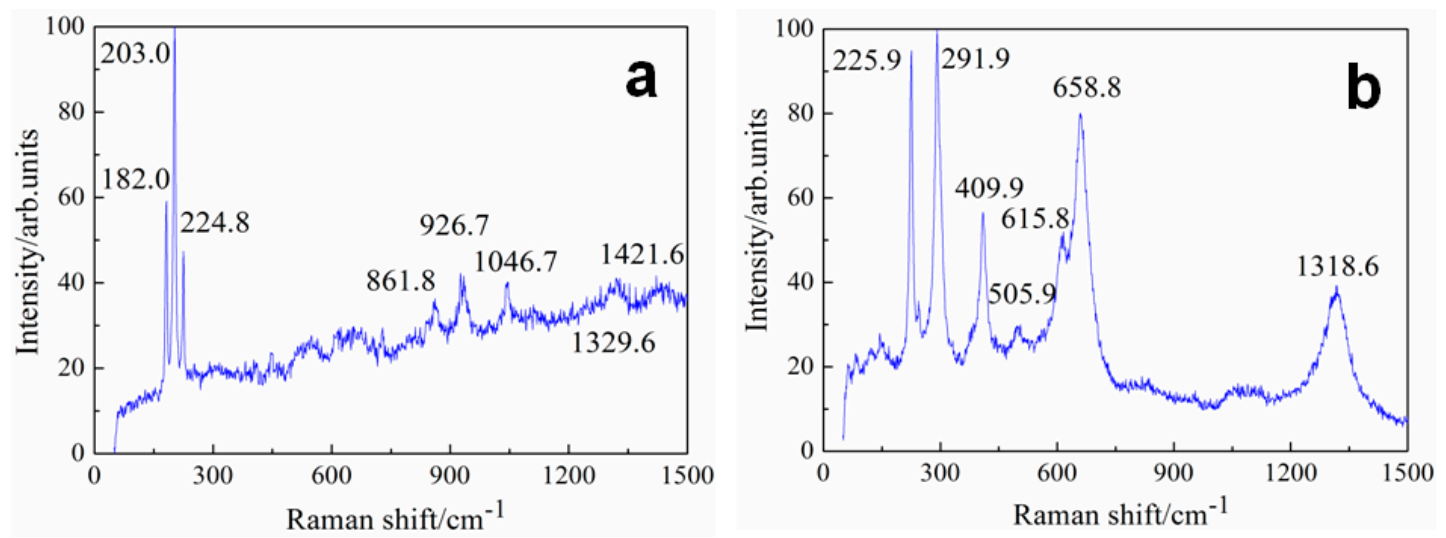

Figure 11. Raman spectrum of wear scar of $\mathrm{Si}_{3} \mathrm{~N}_{4} / \mathrm{a}-\mathrm{Si}: \mathrm{H}$ films under different temperatures: (a) ball; (b) disc.

\subsection{High Temperature Anti-Friction Mechanism of a-Si:H Films}

Figure 12 shows the $\mathrm{CoF}$ of different friction pair materials and a-Si:H films under different tribotest temperatures. At $200^{\circ} \mathrm{C}, \mathrm{CoF}$ is very high (around 0.5) during high temperature tribotests for steel ball and DLC films on steel ball sliding against a-Si:H films. However, CoF is relatively low (around 0.2) for $\mathrm{Si}_{3} \mathrm{~N}_{4}$ and $\mathrm{ZrO}_{2}$ balls sliding against a-Si:H films. The reason maybe that the difference in hardness of the friction pair is low. When the temperature increases to $400{ }^{\circ} \mathrm{C}$, DLC films started to be graphitized, even oxidized and the steel was oxidized with oxygen and water vapor under high contact pressure and high temperature conditions, especially for a-Si:H films on the ball contacting with the flat all the time and resulting in high flash temperature during friction and wear tests. There are mainly iron oxides at $400{ }^{\circ} \mathrm{C}$, thus, $\mathrm{CoF}$ is low at the initial and stable stage. At $600{ }^{\circ} \mathrm{C}$, there is $\alpha-\mathrm{Fe}_{2} \mathrm{O}_{3}$ on the contact surface, and $\mathrm{CoF}$ is low even in the stable stage. There are iron oxides on the ball before the friction test and there are composite oxides of $\alpha-\mathrm{Fe}_{2} \mathrm{O}_{3}$ and $\mathrm{SiO}_{2}$ on flat, therefore, the friction pair is $\alpha-\mathrm{Fe}_{2} \mathrm{O}_{3} / \alpha-\mathrm{Fe}_{2} \mathrm{O}_{3}$ and $\mathrm{SiO}_{2}$, which results in high temperature super-low friction [14]. There are self-generated composite oxides of $\alpha-\mathrm{Fe}_{2} \mathrm{O}_{3}$ and $\mathrm{SiO}_{2}$ on flat surfaces before the tribotest due to a high temperature oxidation reaction at $600^{\circ} \mathrm{C}$. For steel ball, DLC films on ball and $\mathrm{Si}_{3} \mathrm{~N}_{4}$ ball, $\mathrm{CoF}$ decreases with an increase in temperatures. For $\mathrm{ZrO}_{2}$ ball, $\mathrm{CoF}$ is almost the same below $600{ }^{\circ} \mathrm{C}$, and then decreases to super-low friction at $600{ }^{\circ} \mathrm{C}$. It is shown that $\mathrm{Si}_{3} \mathrm{Ni}_{4}$ is suitable for hydrogenated amorphous silicon films according to tribotest results and Raman observations. This is because CoF is higher for $\mathrm{ZrO}_{2}$ ball (0.21) than for $\mathrm{Si}_{3} \mathrm{~N}_{4}$ ball (0.09) at $400{ }^{\circ} \mathrm{C}$ and $\mathrm{CoF}$ is the same for $\mathrm{ZrO}_{2}$ ball (0.07) than for $\mathrm{Si}_{3} \mathrm{~N}_{4}$ ball $(0.07)$ at $600{ }^{\circ} \mathrm{C}$. Moreover, $\mathrm{CoF}$ is higher for steel ball (0.36) than and almost same for DLC ball (0.08) for $\mathrm{Si}_{3} \mathrm{~N}_{4}$ ball (0.09) at $400{ }^{\circ} \mathrm{C}$, and $\mathrm{CoF}$ is almost same for steel ball (0.09) and DLC ball (0.07) as for $\mathrm{Si}_{3} \mathrm{~N}_{4}$ ball (0.07) at $600{ }^{\circ} \mathrm{C}$. Raman measurements show that oxygen reacts with the steel surface and a-Si:H films during the tribological process and produces complex oxide films, which are composed of $\alpha-\mathrm{Fe}_{2} \mathrm{O}_{3}$ and $\mathrm{SiO}_{2}$ on flat. However, not all tribological chemistry reaction products in this tribological process can be employed to improve high temperature anti-friction behaviors. There are different oxidation products due to tribological chemistry on the ball. There are $\alpha-\mathrm{Fe}_{2} \mathrm{O}_{3}$ and $\mathrm{Fe}_{3} \mathrm{O}_{4}$, $\alpha-\mathrm{Fe}_{2} \mathrm{O}_{3}$ and $\mathrm{SiC}, \alpha-\mathrm{Fe}_{2} \mathrm{O}_{3}$ and $\mathrm{ZrO}_{2}$ and $\alpha-\mathrm{Fe}_{2} \mathrm{O}_{3}$ and $\mathrm{Si}_{3} \mathrm{~N}_{4}$ on ball for steel ball, DLC films, $\mathrm{ZrO}_{2}$ and $\mathrm{Si}_{3} \mathrm{~N}_{4}$ ball respectively [15]. The friction pair exhibits high temperature super-low friction when there are hard materials such as $\mathrm{Si}_{3} \mathrm{~N}_{4}$ and soft material such as $\alpha-\mathrm{Fe}_{2} \mathrm{O}_{3}$, which is important for the achievement of super-low friction of the friction system. 


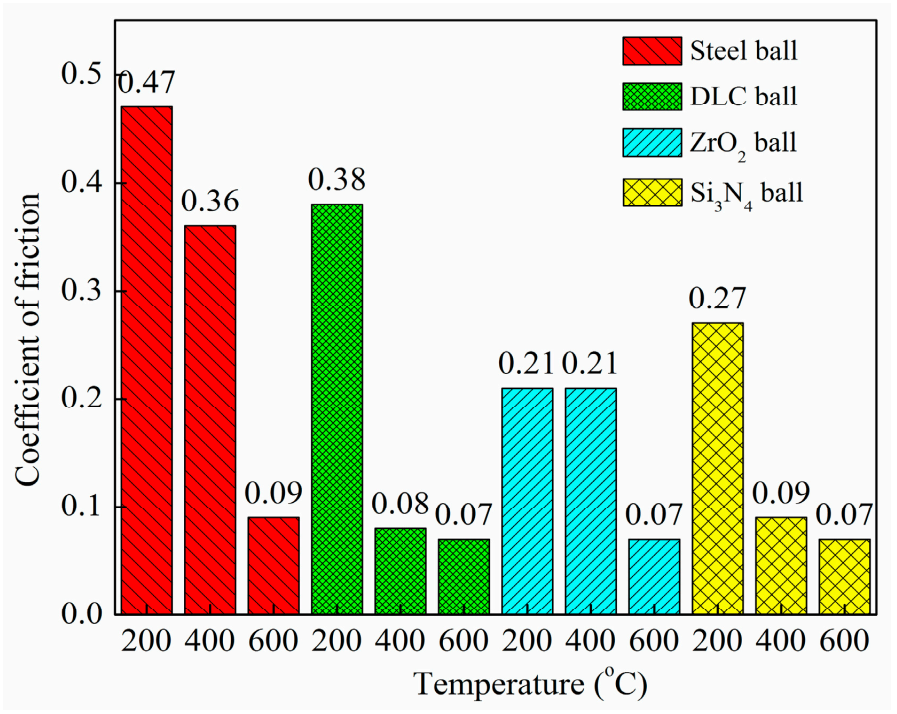

Figure 12. CoF of different friction pair materials and temperatures.

\section{Conclusions}

The effect of the friction pair materials on the antifriction behaviors of a-Si:H films is investigated under high temperature in open air and super-low friction mechanism of a-Si:H films-related friction system under high temperature is also discussed in the present paper. Conclusions can be summarized as follows.

- $\mathrm{CoF}$ of the friction system decreases from 200 to $600{ }^{\circ} \mathrm{C}$ independent of the friction pair materials. $\mathrm{CoF}$ of the friction system is as low as 0.07 at the stable stage at $600{ }^{\circ} \mathrm{C}$ in ambient air. The friction system exhibits excellent high temperature anti-friction behavior.

- The initial CoF is high for steel ball and DLC films on steel ball and low for ceramic ball due to high thermal stability of ceramic materials in ambient air event at $600{ }^{\circ} \mathrm{C}$. The ceramic materials are suitable for tribological applications under high temperature due to the stable and initial low CoF of the friction system.

- Super-low friction of the friction system at the temperature of $600{ }^{\circ} \mathrm{C}$ is achieved independent of the friction pair materials. Moreover, $\mathrm{Si}_{3} \mathrm{~N}_{4}$ is appropriate for a-Si:H films at a wide temperature, especially in high temperatures.

- Super-low friction of the a-Si:H films-related friction system is attributed to high temperature oxidation of a-Si:H films and the metal substrate and the tribochemical products including iron oxides and adhered to surface of ball. The tribochemical reaction generated between the contact surface and oxygen during sliding is beneficial to high temperature antifriction behaviors of hydrogenated amorphous silicon films.

Author Contributions: Conceptualization, Q.Z.; methodology, L.Q.; software, Q.Z.; validation, Q.Z.; Formal Analysis, L.Q.; Investigation, Q.Z.; Resources, Q.Z.; Data Curation, Q.Z.; Writing-Original Draft Preparation, Q.Z.; Writing-Review and Editing, Q.Z. Visualization, L.Q.; Supervision, Q.Z.; Project Administration, Q.Z.; Funding Acquisition, Q.Z.

Funding: The present work is funded by the National Natural Science Foundation of China (No. 51675409), Natural Science Basic Research Plan in Shaanxi Province of China (No. 2019JM-274), the Fundamental Research Funds for the Central Universities (No. xjj2017163) and the Open Project Program of Beijing Key Laboratory of Pipeline Critical Technology and Equipment for Deepwater Oil \& Gas Development (No. BIPT2018001), and the key project of Shaanxi province Science and Technology Department (No. 2017ZDXM-GY-115).

Conflicts of Interest: The authors declare no conflict of interest. The funders had no role in the design of the study; in the collection, analyses, or interpretation of data; in the writing of the manuscript, or in the decision to publish the results. All authors agree to submit the report for publication. 


\section{References}

1. Zhu, S.; Cheng, J.; Qiao, Z.; Yang, J. High temperature solid-lubricating materials: A review. Tribol. Int. 2019, 133, 206-223. [CrossRef]

2. Sliney, H.E. Solid lubricant materials for high temperatures-A review. Tribol. Int. 1982, 15, $303-315$. [CrossRef]

3. Kumar, S.; Panwar, R.S.; Pandey, O. Effect of dual reinforced ceramic particles on high temperature tribological properties of aluminum composites. Ceram. Int. 2013, 39, 6333-6342. [CrossRef]

4. Li, J.; Xiong, D. Tribological properties of nickel-based self-lubricating composite at elevated temperature and counterface material selection. Wear 2008, 265, 533-539. [CrossRef]

5. Zeng, Q.; Eryilmaz, O.; Erdemir, A. Analysis of plastic deformation in diamond like carbon films-steel substrate system with tribological tests. Thin Solid Films 2011, 519, 3203-3212. [CrossRef]

6. Zeng, Q.; Erdemir, A.; Erylimaz, O. Ultralow friction of $\mathrm{ZrO}_{2}$ ball sliding against DLC films under various environments. Appl. Sci. 2017, 7, 938. [CrossRef]

7. Zeng, Q. Thermally induced super-low friction of DLC films in ambient air. High Temp. Mater. Process. 2018, 37, 725-731. [CrossRef]

8. Eryilmaz, O.; Zeng, Q.; Erdemir, A. Superlubricity of the DLC films-related friction system at elevated temperature. RSC Adv. 2015, 5, 93147-93154.

9. Zeng, Q.; Cai, S.; Li, S. High-temperature low-friction behaviors of $\gamma-\mathrm{Fe}_{2} \mathrm{O}_{3} @ \mathrm{SiO}_{2}$ nanocomposite coatings obtained through sol-gel method. J. Sol-Gel Sci. Technol. 2018, 85, 558-566. [CrossRef]

10. Zeng, Q.; Cai, S. Low-friction behaviors of Ag-doped $\gamma-\mathrm{Fe}_{2} \mathrm{O}_{3} @ \mathrm{SiO}_{2}$ nanocomposite coatings under a wide range of temperature conditions. J. Sol-Gel Sci. Technol. 2019, 90, 271-280. [CrossRef]

11. Zeng, Q.; Chen, T. Super-low friction and oxidation analysis of hydrogenated amorphous silicon films under high temperature. J. Non Cryst. Solids 2018, 493, 73-81. [CrossRef]

12. Lengsfeld, P.; Nickel, N.H.; Fuhs, W. Step-by-step excimer laser induced crystallization of a-Si:H. Appl. Phys. Lett. 2000, 76, 1680-1682. [CrossRef]

13. Jiang, Y.; Song, N.; Wang, C.; Pinna, N.; Lu, X. A facile synthesis of $\mathrm{Fe}_{3} \mathrm{O}_{4} /$ nitrogen-doped carbon hybrid nanofibers as a robust peroxidase-like catalyst for the sensitive colorimetric detection of ascorbic acid. J. Mater. Chem. B 2017, 5, 5499-5505. [CrossRef]

14. Erdemir, A. A crystal-chemical approach to lubrication by solid oxides. Tribol. Lett. 2000, 8, 97-102. [CrossRef]

15. Zeng, Q.; Zhu, J.; Long, Y.; De Barros Bouchet, M.I.; Martin, J.M. Transformation-induced high temperature low friction behaviors of $\mathrm{ZrO}_{2}$-steel system at temperatures up to $900{ }^{\circ} \mathrm{C}$. Mater. Res. Express 2019, 6, $0865 \mathrm{f} 5$. [CrossRef]

(C) 2019 by the authors. Licensee MDPI, Basel, Switzerland. This article is an open access article distributed under the terms and conditions of the Creative Commons Attribution (CC BY) license (http://creativecommons.org/licenses/by/4.0/). 